\title{
PENGARUH AKUNTABILITAS, PARTISIPASI MASYARAKAT, PENGETAHUAN KEPALA DESA, DAN TRANSPARANSI TERHADAP KUALITAS INFORMASI LAPORAN KEUANGAN DESA DI KABUPATEN PAMEKASAN
}

\author{
Sofiyah Yatimah Tahir ${ }^{1}$, Evi Malia ${ }^{2}$, Imam Agus Faisol ${ }^{3}$ \\ ${ }^{1,2,3)}$ Fakultas Ekonomi Universitas Islam Madura \\ email:sofiyah040@gmail.com
}

\begin{abstract}
ABSTRAK
Tujuan penelitian ini untuk mengetahui apakah akuntabilitas, partisipasi masyarakat, pengetahuan Kepala Desa, dan transparansi berpengaruh terhadap kualitas informasi laporan keuangan desa. Dengan metodelogi penelitian kuantitatif. Hasil penelitian ini menunjukkan bahwa hasil uji parsial akuntabilitas berpengaruh signifikan terhadap kualitas informasi laporan keuangan desa, partisipasi masyarakat berpengaruh signifikan terhadap kualitas informasi laporan keuangan desa, pengetahuan Kepala Desa berpengaruh signifikan terhadap kualitas informasi laporan keuangan desa, dan transparansi berpengaruh signifikan terhadap kualitas informasi laporan keuangan desa. Berdasarkan uji simultan menunjukkan bahwa akuntabilitas, partisipasi masyarakat, pengetahuan Kepala Desa, dan transparansi berpengaruh signifikan terhadap kualitas informasi laporan keuangan desa di Kabupaten Pamekasan.
\end{abstract}

Kata kunci: Akuntabilitas, Pengetahuan Kepala Desa, Kualitas Informasi Laporan Keuangan Desa

\section{INTRODUCTION}

Kabupaten Pamekasan merupakan salah satu kabupaten yang terletak di pertengahan Pulau Madura. Kabupaten Pamekasan ini berbatasan dengan Laut Jawa di Utara, Selat Madura di Selatan, Kabupaten Sampang di Barat dan Kabupaten Sumenep di Timur. Kabupaten Pamekasan terdiri atas 13 Kecamatan, 178 Desa, dan 11 Kelurahan (pamekasankab.go.id).

Salah satu usaha Presiden Joko Widodo (Jokowi) dalam melakukan pemerataan di seluruh wilayah Indonesia diwujudkan melalui Dana Desa yang dialokasikan khusus dalam APBN. Dana desa pertama kali digulirkan pada tahun 2015 dengan jumlah anggaran sebesar Rp 20,76 triliun. Adapun penyerapannya mencapai $82 \%$ sampai akhir tahun. Di tahun 2016 menjadi Rp 46,9 triliun, kemudian Rp 60 triliun pada tahun 2017, dan direncanakan untuk tahun 2018 akan naik dua kali lipat menjadi Rp 120 triliun (detik.com).
Dalam UU No. 6 Tahun 2014 pengertian keuangan desa adalah semua hak dan kewajiban desa yang dapat dinilai dengan uang serta segala sesuatu berupa uang dan barang yang berhubungan dengan pelaksanaan hak dan kewajiban desa. Hak dan kewajiban sebagaimana pada pasal 71 ayat (1) menimbulkan pendapatan, belanja, pembiayaan, dan pengelolaan keuangan desa. Dalam Permendagri No. 113 Tahun 2014 dinyatakan bahwa prioritas pengelolaan keuangan desa $70 \%$ untuk pelaksanaan pembangunan dan pemberdayaan, dan $30 \%$ untuk penyelenggaraan pemerintah dan pembinaan kemasyarakatan.

Pengelolaan keuangan desa adalah keseluruhan kegiatan yang meliputi perencanaan, pelaksanaan, penatausahaan, pelaporan dan pertanggungjawaban keuangan desa. Dalam mewujudkan tata kelola yang baik dalam penyelenggaraan desa, pengelolaan keuangan desa dilakukan 
berdasarkan hakekat tata kelola yaitu transparan, akuntabel dan partisipasi serta dilakukan dengan tertib dan disiplin anggaran.

Transparansi, akuntabel dan partisipasi dalam pengelolaan keuangan desa merupakan aspek penting dalam menciptakan tata kelola yang baik. Pengelolaan keuangan desa, dikelola dalam masa 1 tahun anggaran yakni mulai tanggal 1 Januari sampai dengan tanggal 31 Desember.

Permendagri No. 113 Tahun 2014 menjelaskan bahwa pengelolaan keuangan desa adalah keseluruhan kegiatan yang meliputi perencanaan, pelaksanaan, penatausahaan, pelaporan dan pertanggungjawaban keuangan desa. Suatu organisasi sektor publik dalam mengelola dana masyarakat dituntut harus mampu memberikan laporan keuangan yang bisa dipertanggungjawabkan. Kepala Desa menjadi penanggungjawab pengelolaan keuangan dan aset desa. PP No. 43 Tahun 2014 pasal 103-104 menyatakan tata cara pelaporan yang wajib dilakukan oleh Kepala Desa. Kepala Desa diwajibkan menyampaikan laporan realisasi pelaksanaan APBDes kepada Bupati/Walikota setiap semester tahun berjalan. Selain itu, Kepala Desa juga diwajibkan menyampaikan laporan pertanggungjawaban realisasi pelaksanaan APBDes kepada Bupati/Walikota setiap akhir tahun anggaran (laporan tahunan). Laporan yang dibuat oleh Kepala Desa ditujukan kepada Bupati/Walikota yang disampaikan melalui camat. Pertanggungjawaban yang tinggi dalam penyajian laporan keuangan akan memicu peningkatan akuntabilitas pengelolaan keuangan desa.

Pengelolaan keuangan desa yang akuntabel merupakan pengelolaan keuangan yang bisa dipertanggungjawabkan mulai dari kegiatan perencanaan, pelaksanaan, penatausahaan, hingga pelaporan keuangan desa. Terwujudnya akutabilitas merupakan tujuan utama dari reformasi sektor publik. Secara umum akuntabilitas diartikan sebagai sebuah bentuk kewajiban untuk mempertanggung jawabkan sebuah keberhasilan atau kegagalan pelaksanaan organisasi dalam mencapai sasaran yang telah diterapkan untuk periode-periode sebelumnya yang dilakukan secara periodik. Menurut Mustofa (dalam Wardana, 2016) Akuntabilitas dalam Pemerintah Desa sangat penting karena merupakan salah satu bentuk media pertanggungjawaban Pemerintah Desa sebagai entitas yang mengelola Dana Desa.

Pengelolaan keuangan desa haruslah konsekuen dan tepat sasaran sesuai dengan Alokasi Dana Desa (ADD) yang telah direncanakan besarnya dana desa yang dicairkan oleh Pemerintah Pusat haruslah mampu dikelola dengan baik jangan sampai Dana Desa yang telah dialokasikan tidak dapat dipertanggungjawabkan dengan baik seperti yang terjadi di Kabupaten Pamekasan baru-baru ini, salah satu Kepala Desa yang terjaring oleh OTT KPK terkait masalah penyalahgunaan Dana Desa dengan total anggaran 250 juta dari Kepala Desa Dasok Kabupaten Pamekasan kebeberapa oknum yang diindikasikan sebagai biaya tutup mulut terhadap pengawasan alokasi dana desa yang diduga ada kekurangan anggaran yang dipakai kurang dari 100 juta yang dipergunakan untuk proyek pembangunan jalan dan paving block di desa tersebut. (https://hukum.rmol.co/).

Akuntabilitas Kepala Desa sebagai pemegang regulasi haruslah dapat memahami setiap proses perencanaan yang ada baik proses perencanaan anggaran maupun proses perencanaan pembangunan, karena Kepala Desa haruslah memiliki kompetensi atau kompeten terhadap setiap regulasi yang ada, sukses dan tidaknya suatu daerah dalam masa jabatannya itu dapat mengindikasikan 
terhadap kompetensi dan kinerjanya di desa tersebut. Karena Kepala Desa dituntut untuk tepat sasaran mengalokasikan dana desa sesuai dengan perencanaan sehingga dapat meningkatkan progresifitas pembangunan dan taraf hidup masyarakatnya.

Menurut Oekley (dalam Ariesta dan Wijaya, 2014) Indikator partisipasi masyarakat meliputi partisipasi fisik, partisipasi buah pikir, partisipasi dana dan partisipasi keterampilan.Partisipasi merupakan hal yang sangat penting dalam pelaksanaan pembangunan. Tanpa adanya partisipasi dari masyarakat, pelaksanaan pembangunan yang berorientasi pada perwujudan kesejahteraan rakyat tidak dapat terwujud. Hal itu dikarenakan masyarakatlah yang lebih tau akan kebutuhannya dan cara mengatasi permasalahan pembangunan yang terjadi didalam masyarakat.

Partisipasi fisik yaitu partisipasi dalam bentuk fisik untuk progresifitas program; partisipasi buah pikir adalah partisipasi atau sumbangsih ide, pendapat untuk memperlancar pelaksanaan program, partisipasi dana adalah partisipasi masyarakat berupa sumbangsih dana untuk memperlancar usaha demi pencapaian program tersebut, partisipasi keterampilan yaitu memberikan stimulasi dengan keterampilan yang ia miliki untuk kegiatan program.

Peranan masyarakat dalam pengelolaan keuangan desa sangat fital. Masyarakat harus ikut andil dalam pengelolaan keuangan desa. Hal ini bertujuan untuk memberikan hak masyarakat untuk ikut berpartisipasi dalam perencanaan penganggaran dan untuk mengawasi penggunaan Dana Desa, guna untuk mencegah terjadinya penyimpangan dalam pengelolaannya, jangan sampai peningkatan anggaran desa tidak memberikan dampak yang signifikan bagi pembangunan dan kepentingan masyarakat di desa.
Keterlibatan masyarakat dalam proses penganggaran adalah hal sangat penting, baik untuk Pemerintah Desa ataupun masyarakat, karena dengan keterlibatan mereka akan berkontribusi terhadap kualitas perencanaan program desa dan memberikan kesempatan bagi mereka dalam menyuarakan apa yang menjadi kebutuhannya. Oleh karena itu, Pemdes harus melibatkan masyarakat dalam proses tersebut, dengan menyediakannya partisipasi dalam setiap perencanaan, pelaksanaan dan evaluasi program desa.

Transparansi merupakan prinsip menciptakan kepercayaan timbal balik anatara pemerintah dan masyarakat, melalui penyediaan informasi dan menjamin kemudahan didalam memperoleh informasi, karena suatu kebutuhan penting masyarakat untuk berpartisipasi dalam pengelolaan keuangan desa. Melalui transparansi maka akan tercipta timbal balik antara pemerintah desa dan masyarakat

\section{LITERATURE REVIEW}

\section{Akuntabilitas Pengelolaan Dana Desa}

Akuntabilitas merupakan konsep yang lebih luas dari stewardship mengacu pada pengelolaan atau suatu aktivitas secara ekonomis dan efisien tanpa dibebani kewajiban untiuk melaporkan, sedangkan accountability mengacu pada pertanggungjawaban oleh seorang steward kepada pemberi tanggung jawab. Tuntutan akuntabilitas publik lebih menekankan pada akuntabilitas horisontal, tidak hanya akuntabilitas vertikal (Renyowijoyo, 2013:14).

\section{Partisipasi Masyarakat Pengelolaan Dana Desa}

Menurut Adisasmita (2006) partisipasi masyarakat adalah keterlibatan dan pelibatan anggota masyarakat dalam laporan keuangan, 
meliputi kegiatan, perencanaan dan pelaksanaan (implementasi) program/proyek pembangunan yang dikerjakan oleh masyarakat. Partisipasi atau peran serta masyarakat dalam pembangunan (perdesaan) merupakan aktualisasi dari ketersediaan dan kemauan anggota masyarakat untuk berkontribusi dalam implementasi program/proyek yang dilaksanakan. Dana anggaran yang tersedia relatif terbatas sedangkan program/proyek pembangunan yang dibutuhkan (yang telah direncanakan) jumlahnya relatif banyak maka perlu dilakukan peningkatan partisipasi masyarakat untuk menunjang implementasi pembangunan program/proyek dalam masyarakat.

\section{Pertanggungjawaban Kepala Desa}

Wasistiono, (2007: 32) Kepala Desa pada dasarnya bertanggung jawab kepada rakyat desa yang prosedur pertanggungjawabannya disampaikan kepada Bupati atau Walikota melalui Camat. Kepada Badan Permusyawaratan Desa, Kepala Desa wajib memberikan keteranagan laporan pertanggungjawaban dan kepada rakyat menyampaikan informasi pokok-pokok pertanggungjawabannya, namun tetap memberi peluang kepada masyarakat melalui Badan Permusyawaratan Desa untuk menanyakan dan atau meminta keterangan lebih lanjut hal-hal yang berkaitan dengan pertanggungjawaban yang di maksud.

\section{Transparansi Pengelolaan Dana Desa}

Permendagri No. 113 Tahun 2014, tentang Pedoman Pengelolaan Keuangan Daerah, menyebutkan bahwa transparan adalah prinsip keterbukaan yang memungkinkan masyarakat untuk mengetahui dan mendapatkan akses informasi seluasluasnya tentang Keuangan Daerah. Dengan adanya transparansi menjamin akses atau kebebasan bagi setiap orang untuk mempeeroleh informasi tentang penyelenggaraan pemerintah, yakni informasi tentang kebijakan, proses pembuatan, dan pelaksanaannya serta hasil-hasil yang dicapai.

\section{METHODS}

Jenis penelitian ini menggunakan metode kuantitatif. Lokasi Penelitian ini dilakukan di seluruh Desa di Kabupaten Pamekasan. Waktu Penelitian ini berlangsung bulan November sampai selesai. Populasi dalam penelitian ini adalah seluruh Desa di Kabupaten Pamekasan. Pengambilan sampel penelitian ini di lakukan dengan menggunakan rumus Slovin, setelah itu dilanjutkan dengan menghitung prosentase. Jumlah Desa di Kabupaten Pamekasan 178 terdiri atas 13 kecamatan.

Teknik pengambilan sampel selanjutnya dalam penelitian ini dilakukan secara random atau acak (Probability Sampling) dengan teknik sampling acak sederhana (Simple Random Sampling). Teknik pengumpulan data dalam penelitian ini menggunakan kuesioner dengan skala likert. Skala likert ini menggunakan lima anggka penilaian yaitu (1) Sangat Tidak Setuju, (2) Tidak Setuju, (3) Kurang Setuju, (4) Setuju, dan (5) Sangat Setuju. Data yang sudah dikumpulkan melalui kuesioner selanjutnya dianalisis menggunakan aplikasi SPSS 23.0 dengan menguji output dari statistic deskriptif, uji asumsi klasik, dan pengujian hipotesisnya.

\section{RESULTS AND DISCUSSIONS} Akuntabilitas Berpengaruh Terhadap Kualitas Informasi Keuangan Desa $\left(\mathbf{H}_{1}\right)$

Dari hasil pengujian peneliti dapat ditarik kesimpulan bahwa hipotesis pertama $\left(\mathrm{H}_{1}\right)$ diterima, bahwa akuntabilitas berpengaruh secara signifikan terhadap kualitas informasi laporan keuangan desa. 
Berpengaruh signifikan karena nilai t-hitung menunjukkan nilai positif, yang berarti bahwa ketika akuntabilitas terhadap kualitas informasi laporan keuangan desa memang benar ada pengaruh. Hasil pengujian parsial diatas menunjukkan bahwa nilai koefisien regresi uji t perolehan t-hitung 2.170, t-tabel 1.671 ( t-hitung $\geq$ t-tabel maka signifikan atau $\mathrm{H}_{1}$ diterima). Nilai signifikansi 0.034 yang menunjukkan bahwa lebih kecil dari pada kriteria yang ada yaitu $0.05(5 \%)$.

Sejalan dengan penelitian yang dilakukan oleh Hamsinar (2017) yang menghasilkan bahwa akuntabilitas berpengaruh signifikan terhadap tingkat kualitas laporan keuangan.

\section{Partisipasi Masyarakat Berpengaruh Terhadap Kualitas Informasi Keuangan Desa (H2)}

Berdasarkan hasil uji hipotesis $\left(\mathrm{H}_{2}\right)$ yang dilakukan peneliti menunjukkan bahwa partisipasi masyarakat berpengaruh signifikan terhadap kualitas informasi laporan keuangan desa. Dikatakan berpengaruh signifikan karena nilai t-hitung menunjukkan nilai positif, sehingga diketahui bahwa nilai koefisien regresi t-hitung diperoleh nilai 4.265, t-tabel 1.671 (t-hitung $\geq \mathrm{t}$-tabel maka singnifikan atau $\mathrm{H}_{2}$ diterima. Nilai signifikansi 0.000. Yang menunjukkan bahwa nilai signifikan lebih kecil dari pada 0.05 . Maka dapat disimpulkan bahwa hipotesis $\left(\mathrm{H}_{2}\right)$ diterima. Maka partisipasi masyarakat tidak hanya ikut serta dalam kegiatan namun juga masyarakat dan para pemangku kepentingan di desa perlu dilibatkan dalam proses perencanaan, pelaksanaan, monitoring, hingga sampai pada tahap evaluasi kegiatan yang telah dilaksanakan. Penelitian ini sejalan dengan yang dilakukan oleh Sugista, (2017) yang menyatakan partisipasi masyarakat dalam pengelolaan keuangan desa berpengaruh pengaruh potitif terhadap pembangunan desa.

Berbeda dengan penelitian yang dilakukan oleh Rahmawati, (2013) Berdasarkan hasil pengujian menunjukkan bahwa partisipasi masyarakat tidak berpengaruh terhadap pengawasan keuangan daerah. Hal ini partisipasi masyarakat menjadi kunci sukses bagi pelaksanaan otonomi daerah, namun kenyataan dilapangan masyarakat tidak selalu berpartisipasi secara aktif dalam proses penyelenggaraan pemerintahan khususnya pada saat penyusunan anggaran (APBD).

Partisipasi masyarakat dalam pengelolaan keuangan desa sangat penting, dimana masyarakat harus ikut andil di dalamnya, bertujuan untuk memberikan hak masyarakat untuk ikut berpartisipasi dalam perencanaan penganggaran dan untuk mengawasi penggunaan Dana Desa untuk mencengah terjadinya penyimpangan dalam pengelolaanya. Partisipas masyarakat di Pamekasan sangat penting dalam proses perencanaan, penganggaraan, pelaksanaan, pengawasan, dan pertanggungjawaban seluruh kegiatan yang didanai melalui APBDes. Dimana kasus yang terjadi di Pamekasan mengenai OTT terkait suap penggunaan Dana Desa. Oleh karena itu, jika ada penyalahgunaan Dana Desa bukan semata-mata menjadi tanggungjawab Pemerintah Desa, melainkan juga tanggungjawab seluruh elemen masyarakat yang ada di desa. Indikator partisipasi masyarakat yaitu keterlibatan dalam perencanaan anggaran, keterlibatan dalam pelaksanaan anggaran, kesempatan masyarakat melakukan pengawasan. Sehingga desa sudah melakukan indikator tersebut. Indikator itu ditunjukkan dengan RPJM di desa yang diikuti oleh masyarakat, keterlibatan masyarakat dalam pelaksanaan 
program BUMDes, serta penggunaan Dana Desa yang dipublikasikan dan dapat diakses oleh masyarakat.

\section{Pengetahuan Kepala Desa Berpengaruh Terhadap Kualitas Informasi Laporan Keuangan Desa $\left(\mathrm{H}_{3}\right)$}

Berdasarkan hasil uji hipotesis $\left(\mathrm{H}_{3}\right)$ yang diajukan peneliti ini diterima atau pengetahuan Kepala Desa berpengaruh signifikan terhadap kualitas informasi laporan keuangan desa. Dikatakan berpengaruh signifikan karena nilai t-hitung menunjukkan nilai positif, dengan nilai koefisien regresi thitung 3.384, t-tabel 1.671 (t-hitung $\geq \mathrm{t}$-tabel maka signifikan atau $\mathrm{H}_{3}$ diterima dengan nilai signifikansi 0.001, yang menunjukkan bahwa nilai signifikan lebih kecil dari 0.05. Bahwa Pengetahuan Kepala Desa berpengaruh signifikan terhadap Kualitas Informasi Laporan Keuangan Desa. Permendagri No.113 menyatakan bahwa dalam siklus pengelolaan keuangan desa merupakan tanggungjawab dan tugas dari Kepala Desa dan pelaksana teknis pengelolaan keuangan desa.

Menurut Putri, dkk (2017) dari hasil penelitian menunjukkan bahwa pengetahuan berpengaruh positif dan signifikan terhadap efektivitas sistem pengendalian internal pemerintah desa. Menurut Onsu, dkk (2015) menyatakan bahwa Kompetensi berpengaruh signifikan terhadap Keberhasilan Pembangunan Desa di Desa Ranolambot. Kepala Desa harus memahami dan mengetahui jalannya laporan keuangan di desa. Karena Kepala Desa dituntut tepat sasaran dalam mengalokasikan Dana Desa sesuai perencanaan sehingga dapat meningkatkan progresifitas dan taraf hidup masyarakat. Indikator pengetahuan Kepala Desa yaitu sifat dan kualitas pemimpin, kecakapan/kemampuan,sifat hubungan antara pemimpin dengan bawahan, kemampuan dan tingkat kematangan bawahan. Sehingga Kepala Desa sudah melakukan serangkain indikator tersebut. Dengan ditunjukkannya Kepala Desa dalam sikap dan kemampuan kepemimpinanya sesuai dengan tugas-tugas desa, kemampuan pola pikir, pengetahun dan pengalaman. Apabila terjadi penyimpangan Dana Desa bisa jadi karena terbatasnya kompetensi Kepala Desa dan perangkat desa. Banyak Kepala Desa yang pendidikannya terakhirnya sekolah dasar atau sekolah menengah pertama. Sementara mereka dituntut mengelola anggaran yang cukup besar dan mempertanggungjawabkan secara akuntabel.

\section{Transparansi Berpengaruh Terhadap Kualitas Informasi Laporan Keuangan Desa $\left(\mathbf{H}_{4}\right)$}

Setelah peneliti melakukan uji hipotesis, maka $\left(\mathrm{H}_{4}\right)$ yang diajukan peneliti diterima atau transparansi berpengaruh terhadap kualitas informasi laporan keuangan desa. Diketahui bahwa nilai koefisien regresi $t$ hitung diperoleh nilai 3.045, t-tabel 1.671(thitung $\geq$ t-tabel maka signifikan atau $\mathrm{H}_{4}$ diterima. Nilai signifikan 0.003 yang menunjukkan bahwa nilai signifikan lebih kecil dari 0.05. Transparansi berpengaruh signifikan terhadap Kualitas Informasi Laporan Keuangan Desa. Berpengaruh signifikan karena nilai t-hitung menunjukkan nilai positif. Transparansi merupakan keterbukaan pemerinyah dalam membuat kebijakan-kebijakan sehingga dapat diketahui oleh masyarakat. Transparansi akan menciptakan akuntabilitas antara pemerintah dan rakyat. Adanya transparansi dan keterbukaan tentang pengelolaan keuangan desa dan informasi mengenai keuangan desa, pemerintah dan aparat desa akan mendapatkan legitimasi masyarakat dan kepercayaan publik. 
Sejalan dengan penelitian yang dilakukan Hamsinar, (2017) menunjukkan bahwa Transparansi Kebijakan Publik berpengaruh positif dan signifikan terhadap kualitas laporan keuangan. Laporan keuangan desa harus transparan. Dengan adanya keterbukaan terhadap laporan keuangan desa maka masyarakat juga mengetahui informasi penggunaan dana, sehingga lebih kecil kemungkinan pemerintah untuk menyalahgunakan untuk kepentingannya sendiri. Kini Pamekasan melaunchingkan aplikasi Sistem Keuangan Desa (Siskeudes) yang merupakan langkah Pemkab Pamekasan menuju tata kelola keuangan desa yang bersih, transparan dan akuntabel. Dengan adanya aplikasi Siskeudes Online akan mampu mewujudkan akuntabilitas dan transparansi dan kecepatan pelaporan pengelolaan keuangan desa. Indikator transparansi yaitu:

1. Kegiatan pencatatan kas masuk maupun keluar dapat diakses dengan mudah oleh masyarakat, serta ada papan pengumuman mengenai kegiatan yang sedang dijalankan.

2. Laporan realisasi dan laporan pertanggungjawaban realisasi pelaksanaan APBDesa diinformasikan kepada masyarakat secara tertulis dan dengan media informasi yang mudah diakses oleh masyarakat.

3. Laporan realisasi dan laporan pertanggungjawaban realisasi pelaksanaan ADD disampaikan kepada Bupati/Walikota melalui camat.

Transparansi di desa ditunjukkan dengan adanya papan informasi/penguman, informasi berupa baliho yang dipasang mengenai penggunaan DD.
Akuntabilitas, Partisipasi Masyarakat, Pengetahuan Kepala Desa, dan Transparansi Berpengaruh Terhadap Kualitas Informasi Laporan Keuangan Desa $\left(\mathbf{H}_{5}\right)$

Setelah dilakukan uji simultan (uji serentak), maka $\left(\mathrm{H}_{5}\right)$ yang diajukan oleh peneliti menunjukkan bahwa nilai koefisin regresi f-hitung diperoleh nilai 76.987 , f-tabel 2.52 (f-hitung $\geq$ f-tabel maka $\mathrm{H}_{5}$ diterima atau signifikan. Nilai signifikansi sebesar 0.000, yaang menunjukkan bahwa nilai signifikan lebih kecil dari 0.05. Dari hasil tersebut dapat disimpulkan bahwa setelah dilakukan uji serentak (uji simultan) akuntabilitas, partisipasi masyarakat, pengetahuan Kepala Desa, dan transparansi berpengaruh signifikan terhadap kualitas informasi laporan keuangan desa.

Permendagri No. 114 Tahun 2014 Kepala Desa menyelenggarakan penyusunan RPJM Des dengan mengikutsertakan unsur masyarakat desa. Kepala Desa memeriksa dokumen rancanagan RPJMDes yang telah disusun oleh tim penyusun RPJM Des. Tim penyusun RPJMDes melakukan perbaikan Secara partisipatif dengan melibatkan seluruh unsur masyarakat desa. Perlibatan masyarakat desa dilakukan melalui musyawarah dusun atau musyawarah khusus unsur masyarakat seperti tokoh masyarakat. Kepala Desa menyampaikan laporan kepada Badan Permusyawaratan Desa setelah menerima laporan dalam rangka penyusunan anggaran desa melalui musyawarah desa.

Akuntabilitas, partisipasi masyarakat, pengetahuan Kepala Desa, dan transparansi berpengaruh terhadap kualitas informasi laporan keuangan desa. Karena laporan pertanggungjawaban, maka masyarakat harus terlibat dalam pelaksanaan Anggaran Desa. Baik masyarakat harus tau mengenai informasi penggunaan Dana Desa, 
penyusunan RPMJDes. Sehingga Kepala Desa harus menguasai dan paham menyusun pertanggungjawaban keuangan desa, serta mengawasi penyaluran Dana Desa.

\section{CONCLUSIONS}

Berdasarkan hasil analisis dan pembahasan yang telah diuraikan pada bab di atas dapat disimpulkan bahwa secara parsial dan simultan yaitu:

1. Akuntabilitas berpengaruh signifikan terhadap Kualitas Informasi Laporan Keuangan Desa, dengan nilai t-hitung sebesar 2.170 dan nilai signifikan sebesar 0.034 .

2. Partsipasi Masyarakat berpengaruh signifikan terhadap Kualitas Informasi Laporan Keuangan Desa, dengan nilai thitung sebesar 4.265 dan nilai signifikan sebesar 0.000.

3. Pengetahuan Kepala Desa berpengaruh signifikan terhadap Kualitas Informasi Laporan Keuangan Desa, dengan nilai thitung sebesar 3.384 dan nilai signifikan sebesar 0.001 .

4. Transparansi berpengaruh signifikan terhadap Kualitas Informasi Laporan Keuangan Desa, dengan nilai t-hitung sebesar 3.045 dan nilai signifikan sebesar 0.003 .

Secara simultan menunjukkan bahwa Akuntabilitas, Partisipasi Masyarakat, Pengetahuan Kepala Desa, dan Transparansi berpengaruh signifikan terhadap Kualitas Informasi Laporan Keuangan Desa. Dengan diperoleh nilai $\mathrm{F}$ hitung sebesar 76.987 dengan signifikan 0.000 .

\section{REFERENCES}

Ariesta, Erlangga dan Holil Wijaya. (2014). Partisipasi Masyarakat dalam Pengelolaan Daur Ulang Sampah di Kelurahan Tugurejo, Kecamatan Tugu,
Kota Semarang: Fakultas Teknik. Universitas Diponegoro Semarang.

Adisasmita, Raharjo. (2006). Pembangunan Perdesaa dan Perkotaan. Yogyakarta: Graha Ilmu.

Andrianto, Nico. (2007). Transparansi dan Akuntabilitas Publik Melalui eGovernment. Malang: Bayumedia publishing.

Bahtiar, Alifahrani Noerma. (2017). Partisipasi Masyarakat Dalam Pengawasan Program Alokasi Dana Desa (Add) Di Desa Panjunan, Kecamatan Sukodono, Kabupaten Sidoarjo. Jurnal Kebijakan dan Manajemen Publik. Vol. 5, No.3 1-14.

http://journal.unair.ac.id/download-fullpaperskmp97fa7892d0full.pdf .November, 30, 2018. Diakses jam 12:35

Ghozali, Imam. (2013). Aplikasi Analisis Multivariat Dengan Program SPSS.

Hamsinar. (2017). Pengaruh Partisipasi Masyarakat, Akuntabilitas dan Transparansi Kebijakan Publik Terhadap Kualitas Laporan Keuangan Pemerintah Daerah dengan Sistem Pengendalian Intern Sebagai Variabel Moderasi (Studi Kasus Kabupaten Pinrang). Makassar: Fakultas Ekonomi dan Bisnis Islam Universitas Islam Negeri Alauddin Makassar.

Ikatan Akuntansi Indonesia-KSAP. (2015). Pedoman Asistensi akuntansi Keuangan.

Kadir, Abdul. (2002). Pengenalan Sistem Informasi. Edisi 1. Yogyakarta: Andi.

Latif, Abdul. (2014). Peran Partisipasi Masyarakat Dalam Peningkatan Pembangunan Desa Di Kecamatan Posigadan. Jurnal Madani. Vol. 4 , No.1 95-111.

http://journal.iaingorontalo.ac.id/indek.p $\underline{\mathrm{hp} / \mathrm{ma}}$

Mursyidi. (2009). Akuntansi Pemerintahan di Indonesia. Bandung: Refika Aditama. 
Muflihah. (2018). Analisis Faktor-Faktor yang Mempengaruhi Kualitas Informasi Laporan Keuangan Pemerintah Daerah Pamekasan: Fakultas Ekonomi Universitas Islam Madura.

Mardiasmo. (2006). Perwujudan Transparansi dan Akuntabilitas Publik Melalui Akuntansi Sektor Publik. Suatu Sarana Good Governance. Jurnal Akuntansi Pemerintahan. Vol. 2. No. 1 Mei 2006.

Onsu, Chaklin Vanesa., dkk. (2015). Pengaruh Kompetensi Kepala Desa Terhadap\Keberhasilan Pembangunan Desa Di Desa Ranolambot Kecamatan Kawangkoan Barat Kabupaten Minahasa.

Prabowo, Septiofera E., Djamhur Hamid., dan Arik Prasetya. (2016). Analisis Partisipasi Masyarakat dalam Pengembangan Desa Wisata (Studi pada Desa Pujonkidul Kecamatan Pujon Kabupaten Malang). Jurnal Administrasi Bisnis (JAB). Vol.33 No. $2 \quad$ April $2016 \quad$ 18-24. administrasibisnis.studentjournal.ub.ac.i $\underline{\mathrm{d}}$

Putri, Cindy Darsana, dkk. (2017). Pengaruh Pengetahuan Peraturan, Kompetensi Sumber Daya Manusia, Monitoring dan Evaluasi Terhadap Efektivitas Sistem Pengendalian Internal Pemerintah Desa. E-jurnal SI Ak Universitas Pendidikan Ganesha. Jurusan Akuntansi Program SI vol.:8. No.:2.

Peraturan Mentri Dalam Negeri No. 113 Tahun 2014 tentang Pengelolaan keuangan Desa.

Peraturan Pemerintah No. 43 Tahun 2014 tentang Peraturan Pelaksanaan UndangUndangNo. 6 tentang Desa.

Peraturan Pemerintah No. 24 Tahun 2005 tentang Standar Akuntansi Pemerintahan.

Peraturan Pemerintahan No. 47 Tahun 2015 tentang Perubahan Atas Peraturan Pemerintahan No. 43 Tahun 2014.
Ranywijoyo, Muindro. (2013). Akuntansi Sektor Publik; Organisasi Non Laba. Edisi Ketiga. Jakarta: Mitra Wacana Media.

Risdiyanto, Anggih. (2014). Pengaruh Kualitas Informasi, Kualitas Sistem, dan Kualitas Layanan Terhadap Kepuasan Pengguna Pada Sistem informasi Klinik. Fakultas Teknik Universitas Negeri Yogyakarta.

Rahmawati, Arini Ayu. (2013). Pengaruh partisipasi Masyarakat dan Transparansi Kebijakan Publik Terhadap Pengawasan Keuangan Daerah Di Kabupaten Sukoharjo. Fakultas Ekonomi Dan Bisnis. Universitas Muhammadiyah Surakarta.

Sugista, Amalia Rizky. (2017). Pengaruh Transparansi, Akuntabilitas, dan Partisipasi Masyarakat dalam Pengelolaan Keuangan Desa Terhadap Pembangunan Desa (Studi Empiris di Kabupaten Lampung Selatan). Lampung: Fakultas Ekonomi dan Bsinis Universitas Lampung.

Solihin, Dadang. (2007). Penerapan Good Governance di Sektor Publik untuk Meningkatkan Kinerja Lembaga Publik. Jakarta: Badan Perencanaan Pembangunan Nasional.

Sugiyono. (2015). Metode Penelitian Kuantitatif, Kualitatif, dan $R \& D$. Bandung: Alfabeta.

Subagio. (2011). Efektifitas Kepemimpinan. Jakarta: Erlangga.

Tumbel, Satria Mentari. (2016). Partisipasi Masyarakat dalam Pengelolaan Dana Desa di Desa Tumaluntung Satu Kecamatan Tareran Kabupaten Minahasa Selatan.

Undang-Undang No. 6 Tahun 2014 tentang Desa.

Usman, Fadlil., dan Sulistyo Dwi Haryanto. (2015). Analisis Kesiapan Pemerintah Desa Dalam Pengelolaan Dana Desa 
(Studi Kasus Pada Pemerintah Desa Pelawad Kecamatan Ciruas Kabupaten Serang).

Umami, Risya dan Nurodin, Idang. (2017). Pengaruh Transparansi dan Akuntabilitas Terhadap Pengelolaan Keuangan Desa. Jurnal Ilmiah Ilmu Ekonomi. Vol.6 Edisi 11. No 74-80.

Wardana, Ibnu. (2016). Akuntabilitas dalam Pengelolaan Keuangan Desa (Studi pada Pemerintah Desa di Kabupaten Magelang). Semarang: Fakultas Ekonomi Universitas Negeri Semarang.

Wasistiono, Sadu., dan Tahir Irwan. (2007). Prospek Pengembangan Desa. Bandung: CV. Fokusmedia.

Widiyanti, Arista. (2017). Akuntabilitas dan Transparansi Pengelolaan Alokasi Dana Desa (Studi pada Desa Sumberejo dan Desa Kandung di Kecamatan Winongan Kabupaten Pasuruan). Fakultas Ekonomi Universitas Islam Negeri (UIN) Maulana Malik Ibrahim Malang. http://www.pamekasankab.go.id. Oktober, 03, 2018. Diakses jam 08:45.

https://finance.detik.com/berita-ekonomibisnis/d-3606172/pemerintah-kucurkandana-desa-sejak-2015-apa-sajahasilnya. November,09,2018. Diakses jam 11:10:59 PM

https://sacafirmansyah.wordpress.com/2009/0 6/05/partisipasimasyarakat/.Desember,02, 2018. Diakses jam 06:54 WIB

https://hukum.rmol.co/read/2017/08/03/30142 8/Begini-Kronologi-Lengkap-OTTKPK-Di-Pamekasan- . November, 09, 2018. Diakes jam 10.48 WIB 